Document downloaded from:

http://hdl.handle.net/10251/102631

This paper must be cited as:

Peris Peris, J.; Acebillo-Baqué, M.; Calabuig Tormo, C. (2011). Scrutinizing the link between participatory governance and urban environment management. The experience in Arequipa during 2003-2006. Habitat International. 35(1):84-92. doi:10.1016/j.habitatint.2010.04.003

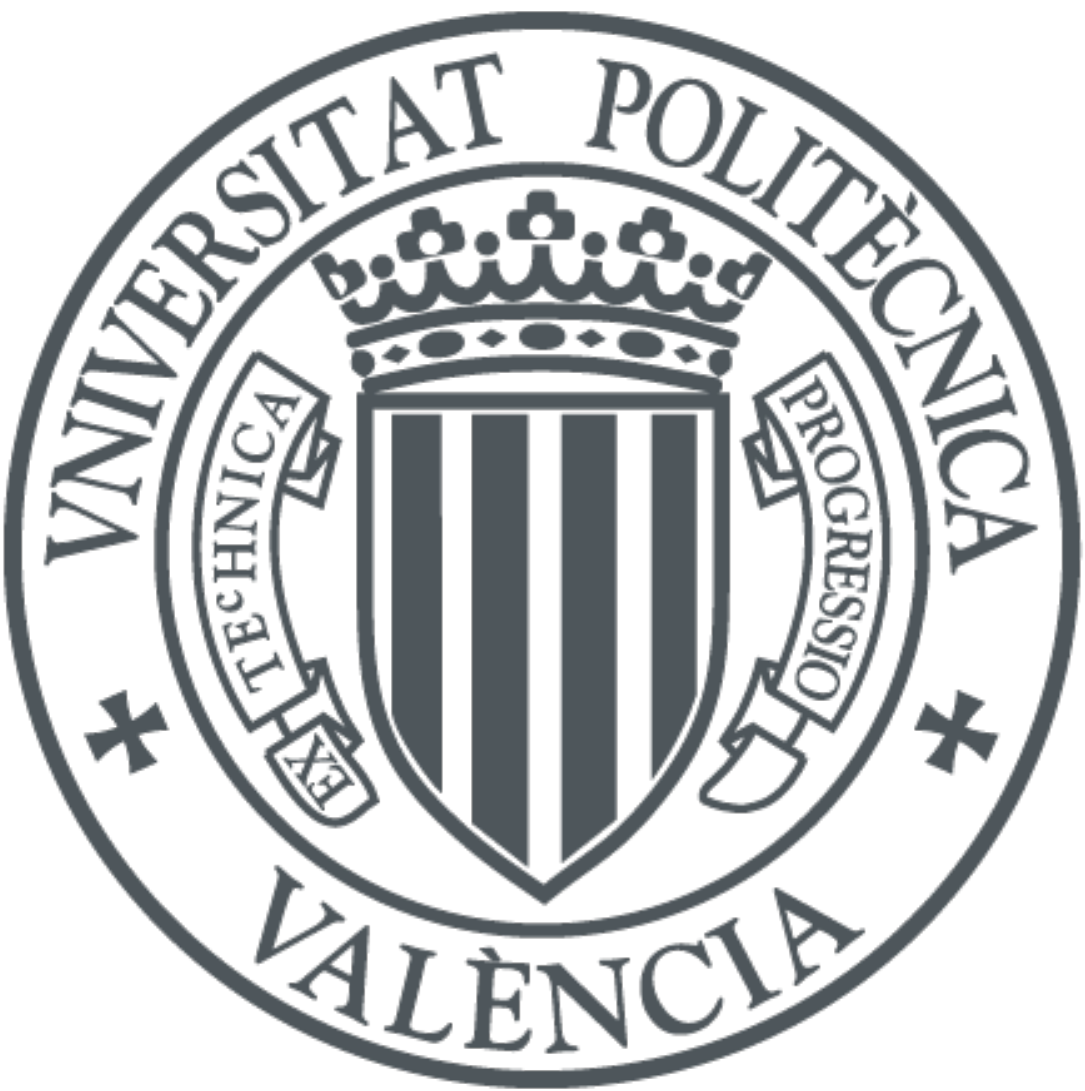

The final publication is available at

http://doi.org/10.1016/j.habitatint.2010.04.003

Copyright PERGAMON-ELSEVIER SCIENCE LTD

Additional Information 


\title{
SCRUTINIZING THE LINK BETWEEN PARTICIPATORY GOVERNANCE AND URBAN ENVIRONMENT MANAGEMENT. THE EXPERIENCE IN AREQUIPA DURING 2003-2006
}

Jordi Peris Blanes, Míriam Acebillo Baqué, Carola Calabuig Tormo

Grupo de Estudios en Desarrollo, Cooperación y Ética

Departamento de Proyectos de Ingeniería

Universidad Politécnica de Valencia

\section{KEY WORDS}

Participation, governance, urban, sustainable development, environment, planning, management

\begin{abstract}
This paper conceptualizes participatory governance as a process of deepening local democracy through the opening of new spaces for civil society and citizens' participation. It explores the link with the urban environment planning and management processes as proposed by UN-HABITAT's SCP/LA21 programmes.

To this end, an analysis of the Urban Environment Management Support Strategy in Arequipa (Peru) promoted by UN-HABITAT and UNEP in 2003-2006 is undertaken to examine how Local Agenda 21 can contribute to institutionalise participatory governance processes which deepen democratic management of sustainable human development in cities.

According to that, we draw some conclusions concerning three different areas. Firstly, the participatory process itself and the role of the working groups, the use of objective data, the connection with citizens and some issues concerning facilitation. Secondly, we go inside accountability and explore the conflictive link between political action and negotiations which take place within a participatory planning process. Thirdly, we discuss institutionalization and the importance of capitalizing previous experiences and existing networks with a particular emphasis on the ones related to environmental education and training.
\end{abstract}




\section{GOVERNANCE AND SUSTAINABLE HUMAN DEVELOPMENT IN URBAN AREAS.}

\section{a. Sustainable human development and the urban environment}

Urban environment is just another dimension of sustainable human development in cities. Interrelationships between environmental, economic, political and social aspects are of such magnitude (Selman \& Parker, 1997) that it is totally unfeasible to approach them in isolation (Alonso \& Sevilla, 2000; Bermejo, 2001). Thus, there is a need for methodological frameworks which enable the development of interventions based on integrality, holistic vision, transversality, interdisciplinarity and long term orientation.

\section{b. Participatory governance}

The notion of governance therefore gains importance as a multiple, complex and conflictual process of interaction among different actors (Graham et al, 2003) for configuring the strategic aspects of the city's sustainable human development (Pieterse, 2000). Governance captures complexity and dynamism of processes (Kooiman, 2004), as well as power relations taking place at their core (Gaventa, 2006).

Participation is widely recognised as one of the essential dimensions of good urban governance (UN-HABITAT, 2004; UNDP, 1997). Thus, we understand participatory urban governance as "effective collaborative planning, decision-making processes (and mechanisms) and implementation to co-ordinate distinctive efforts of the local government, civil society organisations and the private sector towards the progressive attainment of sustainable urban development and local democracy" (Pieterse, 2000:4). According to UNHABITAT, the key ingredient to realizing inclusive, sustainable cities "is neither money, nor technology, nor even expertise, but good governance" (UN-HABITAT, 2002:8).

However, although "governance is apparently becoming one of the problems of our age" (Prats, 2001) it is a diffuse, controversial notion (González, 2007) which has flooded development thinking and debate, helping to open new perspectives and ways of analysis, many of which are somewhat conceptually vague.

In the framework of these discussions, we adopt Gaventa's proposal of participatory governance (Gaventa, 2006) as a process of deepening democracy by empowering citizens and civil society. In comparison to the instrumental conception of participation which has so successfully avoided debates on power relations in development processes, we understand participation in harmony with Sen's notion of agency (Sen, 1999), that is to say people's ability to transform reality through social change (Leal \& Opp, 1998/99). According to that, participation is conceptualized as "the process which facilitates the permanent ability to identify and analyze problems, formulate and plan solutions, mobilize resources and implement them in all areas of people's development needs as they seek to gain control over the processes which affect their lives (Leal \& Opp, 1998/99:7). 
Participatory governance should be thought of as a markedly political process (Mattner, 2004) "produced by historical processes in which collective actors (civil society, state and other) negotiate relations in a pre-existing institutional terrain that constrains and facilitates particular kinds of action" (Houtzager et al, 2003: 29). It is deeply rooted in the relationships and political realities of key groups and includes a systematic consideration of who must be part of the process and under what terms (Mitlin, 2004) and which accountability mechanisms are organised (Cavill \& Sohail, 2004; UN-HABITAT, 2002).

\section{c. Analysis framework}

This conceptualization of participatory governance focuses on the following aspects which will be used to analyse the experience in Arequipa:

- Participation. Legitimacy, credibility and scope of the participatory process is strongly conditioned by whom, how and under what conditions the initiative is launched and how it is perceived. In our analysis we consider three categories of spaces for participation (Cornwall, 2002; Miller et al, 2006; Gaventa, 2005) 1) closed, 2) invited, and 3) claimed ${ }^{1}$. While one key aspect is to determine who takes part and how they do so, another key aspect is to take into account how the initiative connects to others which have taken place or are ongoing in the environment under consideration.

Likewise, it is necessary to consider mobilisation strategies used to involve certain groups of citizens in terms of amplitude, pluralism and representation. Another key aspect is the type of information and expertise considered to be valid. Finally the quality of the participatory process can be assessed in terms of how open and equitable the dialogue and deliberation between actors is (Font \& Blanco, 2003).

- Accountability. This refers basically to capacity of control to guarantee compliance with the responsibilities acquired by the different actors in the process. Although the original meaning of the term refers to the relationship between public administration and citizens (Olmeda, 2005) in this work we consider accountability to be a triangle of mutual responsibilities between public administration, civil society and the private sector with the citizens as the base, in addition to international bodies (Newelll \& Bellour, 2002). Accountability is linked to the idea of transparency in access to information and considers the fight against corruption (UN-HABITAT, 2002) to be essential. At operational level it includes two components (Newell \& Wheeler, 2006) 1) Answerability, or the right to obtain a response and receive explanations on actions

\footnotetext{
${ }^{1}$ According to Cornwall and Gaventa, closed spaces are spaces where decisions are taken by a set of actors with no intention of broadening the process; invited spaces are those where some actors are invited by the authorities to take part in some type of decision making; and claimed spaces are those where less powerful actors burst onto the political scene demanding a greater degree of influence in decisions.
} 
and decisions taken and 2) Enforceability, or the capacity to ensure execution of an action and access to correction mechanisms.

- Institutionalisation. Refers to the in-depth changes which the process of participatory governance generates at the level of values, attitudes, organisations and structures (UN-HABITAT \& UNEP, 1999e). It assumes the transversal integration of sustainable human development principles (SCP/LA21 approaches) in habits, procedures, norms and routines by the different actors intervening in urban environment planning and management.

An understanding of institutionalisation processes requires consideration of specific experiences not as isolated ones but within the framework of a historical and institutional background which conditions and delimits the experiences to a defining point. In this study, we focus on four specific aspects of institutionalisation (UNHABITAT, 1999e): 1) capacity development and learning processes; 2) creation and consolidation of networks and alliances for sustainability; 3) development of a participatory culture; and 4) organisational and legal changes in the public administration.

\section{d. Research methodology}

This research uses a qualitative approach to examine the Urban Environment Management Support Strategy in Arequipa from 2003-2006 as implemented by using UNHABITAT's SCP/LA21 methodology.

From an interpretive social research paradigm (Corbetta, 2003) an attempt has been made to access the viewpoint of the actors involved to understand the meaning and importance attached to the issues raised (Vallés, 1996). Its transferability to other environments must always be approached with caution and limited by considering various types of contextual factors.

The research included a systematisation work in collaboration with UN-HABITAT, the Arequipa Provincial City Council (MPA) and GEA Desarrollo (an Arequipean consultancy which dynamised and guided the urban environmental planning in Arequipa from 20032006). The research included: 1) documentary analysis of the experience and methodology used; 2) semi-structured interviews with 28 key informers ${ }^{2}$, many of them with experience in more than one activity in the process; and 3) participant observation and informal meetings for four months in MPA.

2 Of the 28 interviewees, 8 were women and 20 were men. In total, 15 are members of civil society in Arequipa, 7 belong to the local government ( 5 technicians and 2 politicans), 5 to regional government and 2 to national government. For reasons of privacy, names have been omitted from the extracts shown in the text. 


\section{URBAN ENVIRONMENTAL MANAGEMENT SUPPORT STRATEGY}

The Urban Environmental Management Support Strategy (UES) ${ }^{3}$ in Arequipa during 2003-2006 is led by MPA with the support of UN-Habitat and UNEP. It comes within the framework of UN-HABITAT's Local Agenda 21 and Sustainable Cities programmes (SCP/LA21), an initiative with over fifteen years of experience in more than 30 countries on four different continents.

In addition to the degree of development of the project and the fact that it is not an isolated experience in Peru (Steinberg \& Miranda, 2005; Miranda, 2004), the interest lies in some of the background conceptual considerations. SCP/LA21 are programmes for strengthening capacities in cities mainly from developing countries for planning and managing urban environment and sustainable development based on participatory, intersectoral, bottom-up approaches. They are intended to scaling-up initiatives and mobilising anchor and support institutions. In essence, they are aimed to improve the urban environment through good governance ${ }^{5}$.

\section{a. Characterisation of the city and its environment}

Arequipa is in southern Peru next to the Atacama Desert and in an area of seismic influence (MPA, 2005). With sustained growth since 1940 its HDI is 0.658 , one of the best in Peru (UNDP, 2006). The unemployment rate, however, is above the national average and the incidence of poverty is $44.1 \%{ }^{6}$ concentrated in the urban-rural interface and slum areas in the city centre (UN-HABITAT, 2007).

\footnotetext{
${ }^{3}$ For an exhaustive description on the experience see the systematization document elaborated by authors of this article and published by UN-HABITAT (2007).

${ }^{4}$ Local Agenda 21 (LA21) came out of the United Nations Summit on the Environment and Development in Rio de Janeiro 1992. The 40 chapters in Agenda 21 include Chapter 28 entitled 'Local Authorities' Initiatives in Support of Agenda 21". Although not always promoted by local governments, but necessarily with their support, LA21 is defined by the Internacional Council for Local Environmental Initiatives (ICLEI, 1997) as follows: "Local Agenda 21 is a participatory, multisector process for achieving Agenda 21 goals at local level through the preparation and implementation of a long-term strategic plan that addresses local sustainable development concerns".

5 The SCP/LA21 process consists of the following activities: 1) preparing the environmental profile (diagnosis); 2) conducting the city consultation; 3) establishing the working groups; 4) formulating strategies and plans and implementing demonstration projects. This process is described in detail in the manuals produced by UNHABITAT and UNEP (1998, 1999a, 1999b, 1999c, 1999d, 1999e).

6 Data from 2000 obtained from the Ministry for Women's Affairs and Social Development (MIMDES). For further information see: http://www.mimdes.gob.pe/locales/indicadores/arequipa3.htm [acceso 21/07/2008]
} 
There are 861,746 inhabitants ${ }^{7}$ and 29 districts in the Province of Arequipa, whose local government is organised in the MPA. Each district has its own district municipality. The metropolitan area consists of 17 districts grouped into what is called Ciudad de Arequipa, an entity with no legal jurisdiction which appears defined in the Master Plan for 2002 (MPA, 2002).

Local government bodies are elected by universal suffrage every four years. The Constitution contemplates their autonomy as organs for promoting local development and channels for citizen participation. The country, however, is "possibly the most highly centralised of all Latin American countries" (UNDP, 2006: 43).

The organic structure of the municipalities comprises the Municipal Council and the City Hall. There are also Manager's offices whose main posts are appointed according to confidence criteria ${ }^{8}$. The analysed experience involves the Environment Management Office responsible for coordinating the UES from the MPA.

The UES takes place in the context of important legal changes in Peru related with the transfer of competences and environmental or urban planning aspects ${ }^{9}$. These changes have given local governments the responsibility of establishing a Local Environmental Management System by structuring their internal organs in accordance with the transversal nature of environmental management.

\section{b. Background}

“(...)When HABITAT arrived there were people trained in the subject here. In other words, it is nothing new, that's not to say that no progress was made in Arequipa... They come, but there was already a process here in Arequipa, with its difficulties, but it was there". 20/03/2007- Civil society interviewee

7 According to the 2005 census by Instituto Nacional de Estadística e Informática (INEI) http://www.inei.gob.pe/.

8 Link to the MPA organisational chart at the city council's website: http://www.muniarequipa.gob.pe/noticia.aspx?id=10 [access 21/07/2008]

9 The Ley General del Ambiente (Environmental Law) (No. 28611, October 2005), establishes Peru's National Environmental Policy and defines the Consejo Nacional del Ambiente (National Council for the Environment) (CONAM) as the National Environmental Authority and governing body for the National Environmental Management System (Law No.28245, June 2004). This law, together with the Ley Orgánica de Municipalidades (Organic Law on Municipalities) (law No.27972, May 2003) vests in local governments the power to establish Local Environmental Management Systems. 
The Arequipa UES must be analysed taking into account the city's antecedents since the 1990s in the area of environmental planning and management ${ }^{10}$, antecedents which help to understand the reasons for the progress and drawbacks in participatory governance.

Firstly, atmospheric pollution due to uncontrolled increase in car use provoked an unprecedented social mobilisation in Arequipa, from civil society, private actors and the public administration.

Secondly, from 1999 to 2002 a process of environmental management was started by the MPA, which brought about the creation of the Environment Management Committee within the MPA structure, the implementation of decontamination and environmental protection programmes and the "Integral Plan for Arequipa Strategic and Sustainable development". In this context and boosted by an emergent movement in Peru led by the Forum of Cities for Life (FCPV) ${ }^{11}$, the LA/21 process culminated in July 2000 with the production and approval of the document "Local Agenda 21: Arequipa Urban Environmental Management Plan"12 published by MPA, the Programme for Urban Management Education in Peru (PEGUP), Asociación Civil Labor and the FCPV.

\section{c. Description of the process}

The UES started in 2003 with the production of the GEO Arequipa Urban Environmental Report, promoted by UNEP and MPA. Afterwards, UN-HABITAT comes into play by providing technical and financial support to the MPA and the supporting partner GEA Desarrollo. The aim is to formulate action plans on the Campiña area (historical countryside area in Arequipa) and urban mobility issues, and the establishment of the Environmental Management Information System (EMIS). It is established that the products will be formulated through a participatory, agreed process. Globally, around 75 institutions are involved at different moments of the process.

\footnotetext{
${ }^{10}$ For more information see UN-HABITAT, UNEP and CIUP (2006); UNEP (2006).

${ }^{11}$ FCPV is a national network constituted as a non-profit civil association which serves to group almost one hundred insitutional actors in society: local governments, universities and civil society organisations (NGOs, base organisations and business associations)..

12 The main instruments for executing this plan are the first Plan Estratégico de Arequipa Metropolitana 20022015 and the Plan Director de Arequipa Metropolitana 2002-2015.
} 


\section{Phase 1 Arequipa GEO Report}

"It has been more technical in actual fact. If you really look you can see that there have been more institutional representatives, technical representatives... there has

been very little civil society representation (...) See people's viewpoint and expertise. No, there was none of this in the GEO, but in the action plan at the UN-

Habitat stage there was".

29/03/2007- Civil society interviewee

The Global Environment Outlook (GEO) ${ }^{13}$ seeks to "promote better understanding of the dynamics of cities and their environments, supplying (...) reliable, updated information through integrated environmental assessments" (UNEP, 2006).

MPA is responsible for coordination, with Asociación Civil Labor as technical partner and the University of the Pacific Research Centre. GEA Desarrollo participates in the final drafting of the report. Public institutions are basic information sources. Two workshops and a closed meeting were held. Arequipa GEO was presented to public opinion arousing a lot of media attention.

\section{Phase 2 EMIS unit, City Consultation and Action Plans}

“(...) people don't like, politicians don't like having centralised information and they like it even less if it is computerised, it is better if everything is falling apart, if everything gets lost along the way and that's when one can do things under the table. If everything is clear and ordered there is no hat for anybody to take rabbits out of, it's a fishbowl and visible to everyone.

\section{3/05/2007- Civil society interviewee}

The EMIS Unit is integrated in MPA's organic structure to collect spatial information from different institutions which is generally not shared, not compatible or not updated.

It has provided support both to MPA organs and the technical groups on Campiña and Urban Mobility, which has helped to raise awareness of its utility. In particular, the information provided has helped to reduce the conflict which arose in the Countryside Group ${ }^{14}$ enabling a dialogue more grounded in objective data and less in perceptions.

\footnotetext{
13 In the case of Arequipa, the GEO report played the role which in the SCP/LA21 process corresponds to drawing up the urban environmental profile.

14 The group came about due to the mobilisations in 2003 to prevent the loss of Arequipa countryside as a result of town planning authorisations. It should be remembered that housing in the countryside, and in general in periurban green areas had been identified as a problem area of concern as a result of the 1999-2002 LA21 process. The Arequipa Metropolitan Master Plan for 2002-2015 also refers to this, establishing that these areas (green and natural areas), to prohibit urbanisation, should be zoned as agricultural, environmental
} 
However, when the research was carried out, the future of the EMIS unit was uncertain: UN-HABITAT had financed the initial phase but this did not ensure that it would continue.

City Consultation is a mechanism of the SCP/LA21 Programmes which aims to seek social and political support, forge consensus on priority issues, present and discuss work previously done and involve the different actors.

In Arequipa, the City Consultation lasted three days, and dealt with two of the environmental issues of most concern over the last decade: urbanization of the Campiña area and urban mobility. Around 400 representatives of the public sector, universities, civil society, the private sector and citizens in general attended the inauguration. On the second day, two workshops (one for each Local Technical Groups' issues) were held attended by 40 to 50 people each. On the third day the Urban Pact was signed.

Despite the fact that the number of people involved in the event was relevant, some opinions emerge which consider it as very limited:

"(...), the City Consultation is not a process which lasts from the 7th to 9th June, it is something which must be ongoing and the population must be asked to give its opinion with different tools (...) I don't know to what extent it can really be significant, I think it is symbolic..."

29/03/2007- Civil society interviewee

Once the Urban Consultation was over, Local Technical Group for Urban Mobility was created for participative elaboration of its Action Plan. The Local Technical Group on the Campiña of Arequipa was already working. Both of them were coordinated by GEA Desarrollo.

The aim of the Local Technical Group on the Campiña of Arequipa is to clarify strategic options for its sustainability, proposing short-term actions to stop it from being lost. It brings together 27 institutions which represent local government (MPA and district municipalities) public institutions and regional governments, farmer platforms, the private sector, professional associations, universities and environmental NGOs.

At the initial meetings the working methodology is discussed and approved and three theme-based Committees were established (MPA, 2007a). Each group held around 12 meetings. Then, three plenary sessions were held to debate the proposals, integrate contributions and reach agreements, which are all reflected in the Action Plan for Arequipeña Campiña Sustainability 2007-2010.

The Local Technical Group for Urban Mobility is responsible for formulating Policies for Managing Urban Mobility in Arequipa (MPA, 2007b). It brings together 33 institutions

protection, landscape reserve, environmental preservation and protection areas, among others (MPA, 2007:38). 
representing users (NGO), transport operators, regulating bodies (MPA, Ministries...), professional associations and academic institutions.

The creation and functioning of the group took advantage of the lessons learnt by the Campiña Group, giving rise to a very exhaustive planning of objectives, actors and procedures, expressed in terms of reference and a "Participant Card" detailing the responsibilities and criteria for joining the group. There was also a training course at the start of the process and monthly committee meetings and plenary workshops.

The end of this stage coincided with the electoral campaign period. This created a favourable atmosphere for public statements and a presentation to candidates was carried out to gain their commitment. In turn political actions gave rise to the approval of a municipal ordinance which reflected several of the demands.

According to the participants in both groups, they positively contributed to the work being done:

"Everybody has been involved in the work".

30/05/2007- National-Regional Government Interviewee

However, they also feel that the task is not finished and they show interest in continuing and monitoring the work expressed in the plans:

"After our meeting in December when this finished we have not had another meeting... (...) And I think it hasn't finished, it is only just starting. This document, which I call theoretical, must be followed to give it a practical aspect so that something concrete is achieved, otherwise it will be just a worthless piece of paper".

07/05/2007- Civil society interviewee

\section{ANALYSIS AND DISCUSSION OF THE EXPERIENCE. LESSONS LEARNED}

According to the previous theoretical framework, this section explores the key elements of participatory governance in the specific case of Arequipa UES 2003-2006. Therefore, our analysis focuses on three main areas: the participatory process itself, the issue of accountability and the institutionalization question ${ }^{15}$.

\footnotetext{
15 However, there are important elements of the context which are not discussed in this paper for space's sake that can be influential to a defining point. According to our exploration, these would include: 1) institutional arrangements and legal framework at local, regional and national level, 2) conflictivity, political climate and social cohesion over the issues dealt, 3) actors capacities and prior experiences in the city, 4) social framework and inequality structure for including marginalised groups, 5) the impact of international organisations and bilateral cooperation.
} 


\section{a. On participation}

"There are people who might, shall we say, have less knowledge of the problem but they did know about it. So it was a question of losing one's inhibitions (...)of saying "this is the problem, but I don't know how to approach it"

30/05/2007- Civil society interviewee

SCP/LA21 methodology explicitly considers participation throughout the LA21 process, in both the approach and the mechanisms adopted, and this was observed in the UES.

GEO Arequipa and EMIS Unit understand participation as a way of obtaining information and training actors in their methodology, conceptualisation and implementation. The former is an invited space in which only one NGO requested its participation. The latter is approached as a technical activity. In GEO Arequipa, although it was the MPA who decided the list of participants, the technical perspective prevailed and most of those interviewed did not consider that actors were missing, even though organisations from excluded sectors were not included.

In SCP/LA21 methodology Working Groups themselves are an interesting tool for guaranteeing intersector involvement and the learning of skills for developing deliberative consensus-based processes. In the experience which concerns us here, consensus appears to have been achieved within the Campiña and Mobility Groups, materialising in the formulation of their respective Action Plans. In the Campiña Group the conflict of interest between farmers, builders, civil society and MPA over the regulation of urban growth is explicit. In this regard, it has elements of claimed space and shows less procedural systematisation than the Mobility Group. The Mobility Group also showed initial mistrust due to possible instrumentalisation by the MPA, but this dissolved early on; the atmosphere was much less conflictive and the participants appear more willing to accept differences. It is an invited space, where the working methodology incorporates lessons extracted mainly from the Campiña Group's experience. With regard to representation, in the case, for example, of the Campiña Group it was considered that the significant actors were invited, although in some cases greater involvement was expected and attendance from the private sector (such as construction companies) and district municipalities was missing.

Although, in general, the participatory processes set up in Arequipa through the UES are perceived as realistic by participants, it is assumed they should go further and that the work has not finished. The interviewees understand and value the need to undertake participatory initiatives for reaching agreement on the matters tackled.

But considering participation in LA21 processes from the perspective of equity, citizen involvement and empowerment is not simple. Empowerment processes depend on the 
particular features of each local situation. Invitation to a negotiation space is a first step, but it does not necessarily guarantee that the representatives have the power base or appropriate capacities to put their perspective forward. The empowerment perspective requires progressive, ongoing work to strengthen excluded groups so that they can demand participation in power spaces.

With regard to representation, the experience in Arequipa shows how the strategy adopted in the SCP/LA21 process has been directed essentially at involving certain formally organised collectives and organisations; rather than diffusing (by means of information campaigns or awareness raising action for example) the initiative to the entire population. Nowhere in the process are gender criteria applied and there is no explicit consideration of possible discrimination by ethnic group (indigenous groups), social class or educational level. The interviewees, however, perceived the representative nature of the process as satisfactory, although they stress the need to strengthen organisational capacity in some sectors (farmers, transporters, or the inhabitants of Pueblos Jóvenes -poor human settlements in Arequipa-).

The information considered valid is mainly of a scientific-technical nature and the EMIS Unit played a major role in generating and systematising new information. In the case of the Campiña Group, where positions were contested, the use of objective information has been key to going beyond debates based on subjective or emotional perceptions (according to the coordinator, this has reduced conflictivity).

Thus, SCP/LA21 methodology has an approach to participation which is more pragmatic. Although it makes a valued contribution to the sustainability of decisions, it appears to attach less importance to an examination of the social conditions for equal and inclusive participation with proposals based on such analysis for actions to remedy the situation. This generates the risk of LA21 processes being taken up by technocratic perspectives. In the case of Arequipa, the dichotomy "technification versus citizen appropriation" has not been well resolved as the majority sensation is lack of visibility and connection with the citizens. Dedicating resources to communication and awareness raising, or bringing participants closer to the realities they are discussing, are proposals which may improve this aspect ${ }^{16}$

At methodological level SCP/LA21 highlights the importance of taking care over and planning participatory processes through routines related with the day-to-day nature of this type of process. Case analysis also points in this direction: the systematisation of work (in both groups the calling of meetings and attendance lists were systematised, but not the

\footnotetext{
16 SCP/LA21 methodology speaks of the need to be "on the ground", although the day to day routine or lack of resources may affect attainment of this goal.
} 
minutes and reports), and appropriate organisation and facilitation are key to showing that participation is a "serious" matter.

Finally, certain aspects of participation which need strengthening can be highlighted. Firstly, prior processes of participation and social mobilisation must be taken into account capitalising on the lessons learned, an aspect which was not fully considered in the case studied. Furthermore, there is only superficial consideration of the groups' dynamics. Spending time developing communicative skills, fostering people's knowledge, and generating relationships of trust (something which appears to arise by spontaneous generation) seems important. Also, given that participatory processes mean managing different and often opposing visions, it is important to include the conflict solving perspective. Care must also be taken over the end phase of the work and the farewell, so that the participants themselves evaluate and decide how they dissolve and how the relationships which have been started can be maintained.

Finally, it should be emphasised that in the institutionalisation of LA21 processes, citizen appropriation is fundamental. This is the key to ensuring they are not limited to a mere consultation which relegates the implementation phase to that eternal part of the "agenda" which is never dealt with.

\section{b. On accountability}

"I think that the technical group was formed, how shall I say: "look I have done so many building licenses and now I'm forming my technical group and with that I am

going to shut up any protests which might arise because of the urban licenses".

There is, however, a very interesting statistic, which is that since the technical group was formed, there have been results: there has been only one incorporation in this period. Before that there were over twenty in a single year".

26/04/2007- Civil society interviewee

It is possible to understand a large part of UES actions and motivations from a perspective of accountability. And the process can also be described in terms of generating or destroying confidence between actors, some of whom are perceived by others as being corrupt. Undoubtedly, one of the results of this type of initiatives should be the construction of trust between social and political actors and between them and the public in general.

Although the objectives linked to improving and strengthening accountability are not the end goals of SCP/LA21, there is no doubt on its impact in the case of Arequipa. The most paradigmatic example of this is the creation of the Campiña Group, whose formation and subsequent work was catalysed by reports and accusations from civil society to MPA on urban speculation and corruption.

Globally, the experience in Arequipa provides some lessons on the potential of LA21s for accountability as a dimension of good urban governance. 
SCP/LA21 processes encourage a culture of open, transparent information available to the actors involved and the public (examples of this in the case of Arequipa were the publication of the GEO Report, the generation of information by the EMIS Unit, the City Consultation and the Working Groups themselves). In practice, this contrasts with the information cultures at each local context. In Arequipa, the demand for information from institutions (public and private) is not seen as a right, but as something which depends on goodwill or the pressure exerted.

On the other hand, it should be explored more explicitly the way in which phenomena such as corruption, co-option and the practice for obtaining votes influence the process. In the case which concerns us here for example, actors in both technical groups (Campiña and Mobility) recognise to a greater or lesser extent that they mistrusted the local government or accused it of being corrupt.

Thus, aspects such as conflict management in participatory processes or discussion of the suitability of one of the parties in conflict (in this case the MPA) for leading the process are essential.

On the mechanisms which reinforce the capability to ensure compliance, SCP/LA21 favours the existence and use of formal instruments (agreements, laws, municipal ordinances, standard terms and conditions, minutes and reports...) which may be useful. In addition, as the Campiña Group shows, participation spaces themselves can control public action. In particular, when they include a certain degree of political influence and resort to the mass media, they can become effective in demanding responsibility.

The above mentioned conflictivity in the Campiña Group gave rise to increased control and accountability of MPA in the period in which it functioned. In addition, it has shown that local administration is not monolithic and if some council offices link closely to the process, the global impact can be considerable. This opens the debate on the limits separating political actions from the negotiation of solutions and how LA21 participation spaces combine both. Furthermore, some people consider political action to be a breakdown in the process whereas in the case of the Campiña Group it was undoubtedly key in achieving the objectives.

Recognising diversity, LA21s are an opportunity for local actors to reflect on what accountability means and how to foster debate on its scope and importance. Although there is a widespread view that local government must be responsible and accountable to the public, it still seems difficult to consider that the same type of dynamics for the private sector, civil society and external organisms which finance or intervene in the processes.

This point is significant because exploring forms of control and monitoring the commitments acquired can lead to greater shared responsibility in the process and strengthen action sustainability. 


\section{c. On institutionalisation}

"I think that the most valuable thing has been finding out about experiences and sharing experiences (...)Have you learnt something? Yes". 14/05/2007- Civil society interviewee

On institutionalisationthe study provides certain significant considerations.

SCP/LA21 methodology considers learning and capabilities development to be a core aspect in the process, not only as the acquisition of expertise but in developing skills and values which lead to new behaviours, routines and norms. There is, therefore, a need to resort to systematic learning mechanisms.

In the analysed experience, a strong determination to support capabilities development was observed (for example with training courses) which has not always been suitably integrated, in time or manner, to the global process.

Although the UES has nurtured from professionals and activists trained in the area of consolidated spaces in Peru for environmental education (universities, FCPV and PEGUP), there is no perception of a sufficiently solid integration of these institutions in the process. This is also the case of the already existing mechanisms for training human resources in the municipality. Had this been so, not only would it have contributed to optimising resources and providing synergies, but also new topics, perspectives and contents could have been included in the already institutionalised training programmes.

In addition, although the experience has been seen as enriching, the great challenge consists in going beyond the individual learning of the person participating to make it an organisational learning for the organisation which the person represents.

In relation to the creation and consolidation of network and alliances for sustainability, the interviewees indicated that they had met new actors or had reinforced existing relationships, although no formal networks or alliances were generated to guarantee continuity of the initiative. A participant described it thus:

"We have found new knowledge, new social relations, new friendships, new faces.... Let's hope this moves into society and keeps us linked and in touch"

30/05/2007- National-Regional Government Interviewee

However, the UES found it difficult to capitalize previous experiences and networks, as the ones leaded by PEGUP and FCPV, as well as in getting linked to broader processes which enable regional and national connections as an integral part of institutionalisation. In the UES, the change of government, mutual distrust and differences in agenda between members of the civil society and the recently elected local government are behind the origin of the difficulties which arose in this respect. 
Despite a certain disappointment due to the lack of continuity, there is a perception that participatory culture has been strengthened. It is worth noting that the different actors have assumed the principle of involvement in decision making and the integration of multisector and institutional approaches, as the following quote shows:

"It has helped me to know real situations much better, because sometimes you only see things from your point of view (...)".

30/05/2007. Civil Society Interviewee

As mentioned above, the technical groups have brought together actors who despite their strategic importance had not previously been included in environmental urban planning (pueblos jóvenes, farmers, those with disabilities, transporters...). Although training and information has been provided, no systematic work has been done on strengthening representation platforms of sectors in civil society In this regard, participation has been conceived of as a form of making progress on public matters efficiently and not so much as a process of empowerment.

During the UES there have been organisational and legal changes in the local government. The change of the Office for Environment Management to an executive organ, municipal ordinances and action plans are positive indicators of institutionalisation. However, they do not ensure themselves that the proposals will be implemented, an effective political will with allocated resources is necessary.

The same occurs with the Municipal Environment Committee as its nature of clearly invited space generates doubts over its suitability to organise the actors who have participated.

In relation to interdepartmental coordination the office of human resources have not been integrated which would have helped to strengthen transversality in environmental matters. Motivation in the local government is perceived as a key aspect for providing continuity in the process including both political representatives and technical staff. Therefore it is fundamental to establish formalised relations between the LA 21/SCP experiences and the management instruments commonly used in the municipality (budget, human resources...), and integrate an appropriate critical mass in different areas of local government.

\section{CONCLUSIONS}

The institutionalisation of participatory governance in planning and managing the environment and sustainable human development of cities requires appropriation not only by the public administration but also by civil society and the citizens. As we have argued throughout the paper, deepening democracy through participatory governance implies going beyond the creation of invited consultation spaces and conceiving the issue as an ongoing process of strengthening actors in order to empower them. 
Particularly, and although there are specific contextual issues which have to be taken into consideration carefully, some conclusions can be drawn from the analysis of the SCP/LA21 process in Arequipa during the period 2003-2006. They are expressed as follows:

- Although mistrust may appear at the beginning, Working Groups themselves are an interesting tool for guaranteeing cross-cutting and inter-sectoral involvement and the learning of skills for developing deliberative consensus-based processes. However, they present difficulties once the Action Plans are agreed and it comes to go further and finish the task. In some sense, the implementation phase tends to be relegated to that eternal part of the "agenda" which is never dealt with in the planning process.

- The use of objective information is a key issue for going beyond debates based on subjective or emotional perceptions and, thus, reduce conflictivity. That was the case of the Campiña Working Group, where positions were highly contested.

- The dichotomy "technification versus citizen appropriation" has to be tackled appropriately to avoid lack of visibility and connection with the citizens. Dedicating resources to communication and awareness raising, or bringing participants closer to the realities they are discussing are important issues to be considered.

- The empowerment perspective requires progressive, ongoing work to strengthen excluded groups so that they can demand participation in power spaces. Capacity building and awareness rising is an integral part of urban environment planning and management.

- It is essential to take care over participation itself through routines related with the dayto-day nature of this type of process: systematisation of work, appropriate organisation and facilitation, developing communicative skills, introducing people and generating relationships of trust, managing different and often opposing visions. Care must also be taken over the end phase of the work and the farewell.

- Concerning accountability, it should be explored more explicitly the way in which phenomena such as corruption and co-option influence the process. Therefore, aspects such as conflict management in participatory processes have to be considered.

- There is a debate on the limits separating political actions from negotiation of solutions. The experience shoes how LA21 spaces combine both. Furthermore, some people consider political action to be a breakdown in the process, whereas in the case of the Campiña Group it was undoubtedly key in achieving the objectives

- Concerning institutionalization, sometimes it is difficult to capitalize previous experiences and existing networks due to changes on government, mutual distrust and differences in agenda between members of the civil and local government. However it 
is essential to work on that direction in order to contribute to the sustainability of the initiative.

- In relation to capacity building, it is essential to fully integrate in the process the already existing spaces for environmental education. This is also the case of the already existing mechanisms for training human resources in the municipality. That way, not only resources are optimized and synergies are promoted, but also new topics, perspectives and contents could nurture already institutionalised training programmes.

\section{REFERENCES}

Alonso, A. and Sevilla, E. (2000). El discurso ecotecnocrático de la sostenibilidad. In Bárcena, I, Ibarra, P. and Zubiaga, M. (Eds.), Desarrollo sostenible: un concepto polémico. Bilbao: Servicio Editorial Universidad del País Vasco.

Bermejo, R. (2001). Desarrollo sostenible y humano In Ibarra, P and Unceta, K (Eds.), Ensayos sobre el desarrollo humano. Barcelona: Icaria.

Cavill, S. and Sohail, M. (2004). Strengthening accountability for urban services. Environment and urbanization, 16(1), 155-170.

Corbetta, P. (2003). Metodología y técnicas de investigación social. Madrid: McGraw-Hill.

Cornwall, A. (2002). Making spaces, changing places: situating participation in development. Working Paper No 170. Brighton: Institute of Development Studies.

Font, J. and Blanco, I. (2003). Polis, la ciutat participativa. Barcelona: Diputació de Barcelona.

Gaventa, J. (2005). Reflections on the uses of the Power Cube approach for analyzing the spaces, places and dynamics of civil society participation and engagement. Brighton: Institute of Development Studies.

Gaventa, J. (2006). Triumph, Deficit or Contestation? Deepening the 'Deepening Democracy' Debate. Working Paper No 264. Brighton: Institute of Development Studies.

González, M (2007). ¿Ser como Dinamarca? Una revisión de los debates sobre gobernanza y ayuda al desarrollo. Cuadernos de Trabajo de Hegoa No 42. Bilbao: Hegoa.

Graham, J., Amos, B. and Plumptre, T. (2003). Principles for good governance in the 21st century. Policy Brief No 15. Ottawa: Institute on Governance.

Houtzager, P, Gurza Lavalle, A and Acharya, A (2003). Who participates? Civil society and the new democratic politics in São Paulo, Brazil. Working Paper No 210. Brighton: Institute of Development Studies.

ICLEI . (1997). Local Agenda 21 Survey. UN Department for Policy Coordination and Sustainable Development.

Kooiman, J (2004). Gobernar en gobernanza. Instituciones y desarrollo ,16, 171-194. 
Leal, P and Opp, R (1998/99). Participation and development in the age of globalization. Development Express, 7 .

Mattner, M (2004). Power to the people? Local governance and politics in Vietnam. Environment and urbanization, 16(1), 121-127.

Mitlin, D (2004). Reshaping Local Democracy. Environment and urbanization, 16(1), 3-8.

Miller, V, Lisa V, Molly R \& Cindy C (2006). Power. Concepts for Revisioning Power for Justice, Equality and Peace. Making Change Happen No 3. Washington DC: Just Associates.

Miranda, L (2004). Cities for life revisited: capacity-building for urban management in Peru. Environment and urbanization, 16(2), 249-261.

MPA (2002). Plan Director de Arequipa Metropolitana 2002-2015. Arequipa: Municipalidad Provincial de Arequipa.

MPA (2005). Perspectivas del Medio Ambiente Urbano: GEO Arequipa. Arequipa: Municipalidad Provincial de Arequipa y PNUMA.

MPA (2007a). Plan de Acción para la Sostenibilidad de la Campiña Arequipeña 2007-2010. Arequipa: Municipalidad Provincial de Arequipa and UN-HABITAT.

MPA (2007b). Políticas para la Gestión de la Movilidad Urbana en Arequipa 2007. Arequipa: Municipalidad Provincial de Arequipa and UN-HABITAT.

Newell, P and Bellour, S (2002). Mapping accountability: origins, contexts and implications for development, Working Paper No 168. Brighton: Institute of Development Studies.

Newell, P and Wheeler, J (2006). Making Accountability Count, IDS Policy Briefing No 33. Brighton: Institute of Development Studies.

Olmeda, J A (2005). Ciencia de la Administración. Teoría de la organización y gestión pública. Madrid: UNED.

Pieterse, E (2000). Participatory Urban Governance. Nairobi: UN-HABITAT.

Prats, J (2001). Gobernabilidad democrática para el desarrollo humano. Instituciones y desarrollo $10,103-148$.

Selman, P and Parker, J (1997). Citizenship, Civicness and Social Capital in Local Agenda 21, Local Environment 2(2), 171-184.

Sen, A (1999). Development as freedom. Oxford University Press.

Steinberg, F, Miranda, L (2005). Local Agenda 21, capacity building and cities of Peru. Habitat International 29, 163-182.

UNDP (1997). Governance for sustainable human development. UNDP policy document. 
UNDP (2006). Informe sobre Desarrollo Humano Perú 2006. Hacia una descentralización con ciudadanía. PNUD.

UNEP (2006). Evaluaciones integrales ambientales en Ciudades de América Latina y el Caribe: Proyecto GEO Ciudades. UNEP.

UN-HABITAT (2002). The Global Campaign on Urban Governance. Concept paper. Nairobi: UNHABITAT.

UN-HABITAT (2004). Urban Governance Index. Conceptual Foundation and Field Test Report. Nairobi: UN-HABITAT.

UN-HABITAT (2007). SCP/LA21 en Arequipa. Serie Estrategia de Apoyo a la Gestión Urbano Ambiental. Nairobi: UN-HABITAT.

UN-HABITAT \& UNEP. (1998). Sustainable Cities Programme. Approach and Implementation. The SCP Source Book Series. Nairobi: UN-HABITAT \& UNEP.

UN-HABITAT \& UNEP. (1999a). Preparing the Environmental Profile. The SCP Source Book Series. Volume 1 . Nairobi: UN-HABITAT \& UNEP.

UN-HABITAT \& UNEP. (1999b). Organizing, Conducting and Reporting an SCP City Consultation. The SCP Source Book Series. Volume 2 . Nairobi: UN-HABITAT \& UNEP.

UN-HABITAT \& UNEP. (1999c). Establishing and Supporting a Working Group Process. The SCP Source Book Series. Volume 3 . Nairobi: UN-HABITAT \& UNEP.

UN-HABITAT \& UNEP. (1999d). Formulating Issue Specific Strategies and Action Plans. The SCP Source Book Series. Volume 4 . Nairobi: UN-HABITAT \& UNEP.

UN-HABITAT \& UNEP. (1999e). Institutionalising the Environmental Planning and Management (EPM) Process. The SCP Source Book Series. Volume 5 . Nairobi: UN-HABITAT \& UNEP.

Valles, M (1996). Técnicas cualitativas de investigación social. Madrid: Síntesis.

UN-HABITAT, UNDEP and CIUP (2006). La experiencia peruana en planificación y gestión urbanoambiental. UN-HABITAT, PNUMA y CIUP. 